\title{
reviews
}

THE first volume of this textbook, dealing with the principles of the subject, appeared in 1962 and reached a second edition in 1968. Good of its kind, it necessarily follows fairly conventional lines. The second volume aims at global history in a way that has never previously been attempted. It was about threequarters complete when H. H. Read died in 1970, in his 80th year; Professor Janet Watson is to be congratulated on bringing the eagerly-awaited work to fruition.

The method adopted is to integrate the broad record of stratigraphy of rocks formed at or near the Earth's surface with structural, magmatic and metamorphic events which occurred at depth within the crust. The evidence comes fundamentally from geological mapping at the surface, with data on the third dimensions derived from valleys, mines, boreholes and the indirect probing of geophysics. The process has been carried to a very variable degree in different parts of the world, but there is no doubt that the time is ripe for synthesis on the scale attempted here. Moreover, the classical method of time-assessment from fossils has now been carried far back into the Cryptozoic, and the newer method of radiometric dating gives a valuable control over Cryptozoic and Phanerozoic alike, once its limitations have been appreciated. The authors point out, however, that they have had to place severe limitations upon the amount of stratigraphic (and, therefore, palaeontological) detail given. The framework is, in fact, not stratigraphy but tectonics and this follows very suitably from the last chapter of Volume 1 ("A pattern of earth history") which drew a sharp distinction between stable regions of the crust and belts of mobility. The history of the

\section{New geological framework}

Introduction to Geology. Vol. 2: Earth History. By H. H. Read and Janet Watson. Part 1: Early Stages of Earth History. Pp. xii +221 . $£ 5.95$ board; $£ 2.95$ paper. Part 2: Later Stages of Earth History. Pp. xii +371 . $£ 6.95$ board; $£ 3.95$ paper. (Macmillan: London and Basingstoke; distributed in the USA by Halsted Press; May 1975.)

mobile belts is adopted as the framework for Volume 2, though the cratons of Precambrian time, the interior lowlands, epicontinental basins and forelands are by no means forgotten.

Volume 2 is issued in two parts in order to make possible the publication of the paperback edition. Part I deals with the first $2.9 \times 10^{9}$ years, covering Precambrian events up to the later Proterozoic. As far as I know, this is the first time that a global synthesis of the Precambrian, involving all the continents including Antartica has been attempted. For each continent, an outline of the tectonic pattern is first given; then the stages by which the rocks older than 900 Myr have been formed is set forth. A concept of a series of cycles emerges; the ending of a cycle brings stability to tracts that were formerly mobile, contributing to the growth of cratons; but the initiation of a new cycle may affect tracts that were formerly stable.

Many interesting problems for future solution come directly from this synthesis.
Though it seems unlikely that a stratigraphic classification like that adopted throughout the world for the Phanerozoic will ever become feasible for the ancient rocks, some correlations certainly begin to emerge, as Figure 10.1 shows in the book. Indeed Part I will make good reading for those involved in the Precambrian priority area of the International Geological Correlation Programme of UNESCO/IUGS.

Part II commences with a chapter on new themes in Earth history which provides a convenient way of dealing with continental drift and palaeoclimatic change. The method used in Part $I$ is then readopted and the framework again established on mobile belts, but belts which will be much more familiar to most readers than those described in Part I: the Caledonian, HercynianUralide, Alpine-Himalyan and Cordilleran. The interior platforms of little distorted cover-rocks resting on Precambrian or later basement receive due attention, and the break up of the great ancient southern continent of Gondwanaland is described. This leads on to the current concepts of global tectonics, the opening of the Atlantic and Indian oceans, and the outward circumferential push around the Pacific.

Even if the authors have had to scale down the over abundant geological detail, they have succeeded in following those aspects of geological process that can be traced throughout the full span of Earth history, at the same time pointing a finger at a few, like banded ironstone formation or the detrital transport of uraninite, that long ago ceased for ever. Surprisingly in this historical essay, the useful rocks and minerals are not forgotten, but appear in their due genetic positions.

Kingsley Dunham
TRANSPORT of peptides across biological membranes, first discovered in microorganisms, is now recognised to be of major significance in the intestinal absorption of amino- $N$, yet little is known of other roles of peptide transport.

The variety of peptides $-20^{2}=400$ dipeptides alone and the range of their biological activities is astonishing. Some are hormones, others vasoactive. There are peptides called 'smugglins' that carry otherwise impermeant molecules piggyback across membranes. Peptides contribute sig-

\section{Peptide transport}

Peptide Transport in Protein Nutrition. (North-Holland Research Monographs, Frontiers of Biology, Volume 37.) Edited by D. M. Matthews and J. W. Payne. Pp. xxii +503 . (NorthHolland: Amsterdam and Oxford; American Elsevier: New York, 1975.) Dfl. $130 ; \$ 54.25$.

nificantly to the flavour of foodstuffs. Some taste extremely sweet, others containing acidic and neutral amino acids taste sour but (see page 55) Mrs Beeton's recipe for tasty beef tea produces a satisfactory mixture.

The Editors and their eight colleagues have succeeded in delving into diverse disciplines to produce a generally well-balanced account of knowledge of peptides, with the emphasis on nutrition.

This is an expensive book (10 pages $=\$ 1.00)$, but an essential acquisition for libraries. It will be read with profit by biochemists, clinicians, nutritional scientists and food technologists.

Dennis Parsons 